\title{
DN4 QUESTIONNAIRE IN FAMILY PRACTICE FOR EVALUATION OF CLINICAL MANIFESTATIONS OF NEUROPATHIC PAIN IN TYPE 2 DIABETES PATIENTS TREATED BY LIGHT THERAPY
}

\author{
N. R. Makarchuk \\ I. HORBACHEVSKY TERNOPIL STATE MEDICAL UNIVERSITY, TERNOPIL, UKRAINE
}

Background. Peripheral diabetic polyneuropathy (DPN) is one of the most frequent neurological complications of diabetes mellitus (DM). Despite the large number of pharmacological agents, its treatment is not sufficiently effective, which necessitates the search for new therapies.

Objective. The aim of the study was to increase the effectiveness of treatment of neuropathic pain in the patients with diabetic polyneuropathy by incorporating procedures using polarizing polychromatic non-coherent light (Bioptron light therapy) into the complex therapy of this disease.

Methods. We examined 67 patients with type 2 diabetes complicated with diabetic polyneuropathy. Patients were divided into two groups: group 1 consisted of 32 patients, who received standard treatment; group 2 comprised 35 patients, who additionally underwent 12 light therapy treatments by means of the Bioptron Physiotherapy Unit. The evaluation of neuropathic pain intensity was performed using a modified questionnaire DN4.

Results. A positive clinical effect of treatment was evidenced in both groups in 12 days of treatment. In 3 months, the intensity of complaints was significantly lower $(p<0.05)$ only in the group with additional use of polarizing light. In 6 months, the positive effect of the therapy was leveled in the patients of both groups.

Conclusions. The use of the DN4 questionnaire with a modified scale for assessing the parameters of neuropathic pain can optimize its diagnosis. The light therapy procedures together with the standard complex therapy of diabetic polyneuropathy increase the clinical efficacy of neuropathic pain treatment and help to preserve the therapeutic effect within 3 months.

KEY WORDS: diabetic polyneuropathy; neuropathic pain; DN4 questionnaire; polarized polychromatic noncoherent light (Bioptron).

\section{Introduction}

Peripheral diabetic polyneuropathy (DPN) is a typical early and most frequent complication of diabetes mellitus (DM) [1]. It develops due to affection of nerve fibers, caused by diabetes and occurs in more than $50 \%$ of patients with this illness. Polyneuropathy is revealed in both young and elderly patients with type 1 and type 2 diabetes mellitus [2]. There is no single classification of peripheral diabetic neuropathy. Some authors recommend defining hypohyperglycemic, generalized, focal and multifocal types (Thomas P.K. 1997); whereas others insist on singling outing asymptomatic, symptomatic and marked symptoms (Dyck P. J. 1999) or mono, polyneuropathy and autonomic polyneuropathy (I. I. Dedov et al., 2002). According to the protocol of medical care [11], peripheral polyneuropathy is divided into somatic (motor, sensory and sensory-motor), vegetative and mononeuropathy.

Corresponding author: Nadiya Makarchuk, Department of First Emergency Medical Aid and Emergency Medical Treatment, 1 Maydan Voly, Ternopil, 46001, Ukraine

E-mail: nadiya_rm@ukr.net

Phone number: +380971322995
To diagnose pathological process in the nervous tissue Boulton et al (2005) suggested allocating three clinical forms of peripheral DPN (silent, acute pain and chronic pain). Chronic pain form of DPN is the most commonly reveled in the patients with diabetes [1].

The severity of this complication depends on its clinical consequences, in particular, trophic disorders and neuropathic pain, which adversely affect patients' quality of life. A number of questionnaires are used to diagnose neuropathic pain [3]. DN4 questionnaire, being one of the most practical, where a positive response to four or more questions out of ten substantiates 'neuropathic pain' diagnosis, is used as a screening to detect neuropathic pain syndromes [4].

Despite the large number of pharmacological agents, treatment of patients with diabetic polyneuropathy is not sufficiently effective [5, $6,7]$, which necessitates the search for new methods of treatment. Since the mid-80s, there have been physiotherapeutic devices that emit visible (wavelength 80-3400 nm) linearly polarized (95\%) incoherent (desynchronized in time and space) low-energy (non-destructive, 
with the energy flux intensity of $40 \mathrm{~mW} / \mathrm{cm}^{2}$ ) (Pyler) light, and the light stream, transformed by polarization, that lacks both ultraviolet and a significant part of the infrared rays. Studies conducted at the end of the last century proved a positive effect of physiotherapeutic procedures using this light for treatment of diseases with lesions of peripheral nerves $[8,9,10]$. The aim of the study is to increase the effectiveness of treatment of neuropathic pain in patients with diabetic polyneuropathy by including light therapy procedures into the complex treatment of this disease.

\section{Methods}

67 patients were examined (36 males (53.7 \%) and 31 females (46.3\%)) with type 2 diabetes and DPN. The diagnosis of DPN was based on anamnesis and clinical examination data. the age of the examined persons ranged from 45 to 65 years old (mean age $57.0 \pm 5.2$ years old). Duration of diabetes mellitus was from 4 to 19 years (average duration $9.4 \pm 3.7$ years), and of DPN was from 1 to 12 years (which averaged $5.5 \pm 2.9$ years).

For the convenience of systematization and objectification of data comparing, all examined patients were divided into two groups: the $1^{\text {st }}$ control group comprised 32 patients with type $2 \mathrm{DM}$ and DPN, who received standard treatment according to a unified clinical protocol of primary and secondary (specialized) medical care (No.1118, dated December 21, 2012) [11]. The $2^{\text {nd }}$ group involved patients undergoing standard treatment together with 12 light therapy treatments by means of the Bioptron Physiotherapy Unit [12]. The duration of the procedure was 10 minutes with a directed flow of light on the lower limbs. General characteristic features of patients with diabetes are presented in Table 1.

Clinical examination of patients was performed before the treatment and on the $12^{\text {th }}$ day after the beginning of the treatment.

Neuropathic pain was diagnosed using the modifi questionnaire DN4 $(2005)[13,14]$. The questionnaire structure included two blocks of questions: 7 questions of the fi block revealed sensory symptoms, including spontaneous pain (burning, painful cold, electric shocks), paresthesia and dysesthesia (tingling, pins and needles, numbness, itching); three conclusions of the physician, based on the clinical examination, which comprised the second block, give the physician the opportunity to identify the allodynia and negative sensory symptoms. Neuropathic pain was set at a score of 4 or more points.

For the details of each question, we modified the DN4 questionnaire by ranging the intensity (scale 1 to 10) of the sensations listed in the first question block.

Evaluation of the results was carried out at the admission of patients to the hospital and in 12 days after the start of diabetic polyneuropathy treatment. Long-term results of the therapy were administered in 3 and 6 months by performing the call-in poll among the patients using the first question block of the questionnaire.

The analysis and processing of statistical data of clinical examinations results were carried out on a personal computer using STATISTICA 10 and MS excel XP application packages. All data are presented as mean value and standard deviation $(M \pm \sigma)$. Relations between continuous variables were examined by the Pearson correlation coefficient $\chi^{2}$. Comparison of the rates between the groups was carried out using the Student T-test, and those within the group were compared using Wilcoxon matched paired test. The difference in rates was considered statistically significant at $p<0.05$.

\section{Results}

According to the DN4 questionnaire, 49 $(73.1 \%)$ of the surveyed patients suffered neuropathic pain before treatment, which is consistent with the literature [15]. no signifi differences between the groups were noticed before treatment ( $p>0.05$ ) (Table 2 ).

Subjective symptoms in the general group of patients were presented as follows: $67.2 \%$ of patients suffered burning sensation, while $31.34 \%$ experienced painful cold. $74.6 \%$ of people were disturbed by tingling. $40.29 \%$ of patients with diabetes sensed electric shocks. Pins and needles sensation and that of numbness troubled $58.2 \%$ and $59.7 \%$ of patients respectively. $34.3 \%$ of respondents had complains of itching. The

Table 1. General characteristic features of the patients $(M \pm \sigma)$

\begin{tabular}{|l|c|c|c|}
\hline $\begin{array}{c}\text { Characteristic features } \\
\text { of the groups of patients }\end{array}$ & $\begin{array}{c}1^{\text {st }} \begin{array}{c}\text { group, } \\
\mathrm{n}=32\end{array} \\
\text { Age, years }\end{array}$ & $\begin{array}{c}2^{\text {nd }} \text { group, } \\
\mathrm{n}=35\end{array}$ & $\mathrm{p}$ \\
\hline Duration of DM, years & $8.7 \pm 5.2$ & $55.6 \pm 4.9$ & $\mathrm{p}>0.05$ \\
\hline Duration of DPN, years & $4.9 \pm 2.8$ & $10.1 \pm 4.0$ & $\mathrm{p}>0.05$ \\
\hline \multicolumn{3}{|l|}{} & \\
\hline
\end{tabular}


Table 2. Follow-up of neuropathic pain severity in the examined groups of patients with diabetes mellitus according to the DN4 questionnaire before and after treatment $(M \pm \sigma)$

\begin{tabular}{|c|c|c|c|}
\hline & $1^{\text {st }}$ group & $2^{\text {nd }}$ group & $P$ \\
\hline Before treatment & $4.7 \pm 1.4$ & $4.8 \pm 1.6$ & $\mathrm{p}>0.05$ \\
\hline After treatment & $3.4 \pm 1.5$ & $2.9 \pm 1.2$ & $\mathrm{p}>0.05$ \\
\hline
\end{tabular}

Notes: * - significant difference before and after treatment $(p<0.05)$.

objective examination of the patients' lower extremities proved that the pain was localized in the area with a reduced sensitivity to touching (in $70.2 \%$ ), pricking (in $37.3 \%$ ) and in the area of irritation with a brush (in $19.4 \%$ ), indicating a tactile and sensory sensitivity disturbance. The intensity of each of the following complaints before treatment in the examined groups of patients is presented in Fig. 1.

After the course of treatment, a decrease in the level of neuropathic pain was evidenced, together with a positive dynamics of the intensity of subjective complaints of the patients.

The analysis of data of the DN4 questionnaire proved a decrease in the signs of neuropathic pain by $41.7 \%\left(\chi^{2}=2.5 ; p>0.05\right)$ in the patients of control group, and by $64.0 \%\left(\chi^{2}=27.6 ; p<0.05\right)$ in the group with additional light therapy procedures. The rate of neuropathic pain presence after the course of treatment was much lower in the $2^{\text {nd }}$ group.

The study of individual rates of neuropathic pain in each of the groups on the $12^{\text {th }}$ day after

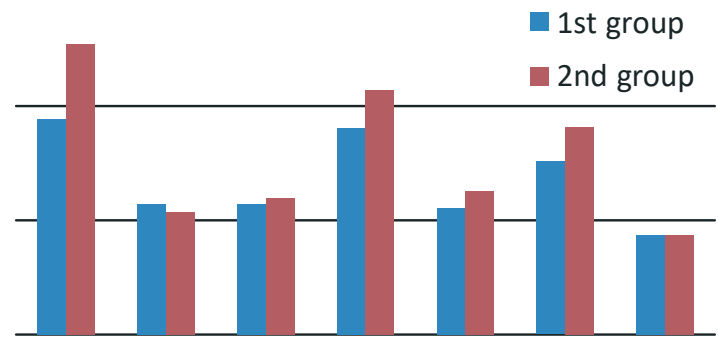

Before treatment

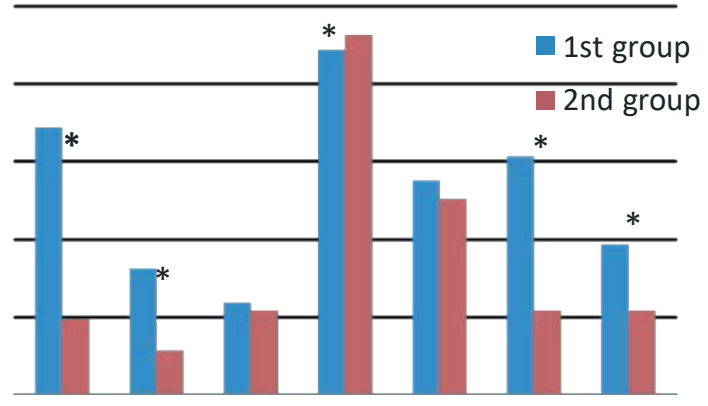

In 3 months after treatment the beginning of treatment proved that the patientsofthe $1^{\text {st }}$ and the $2^{\text {nd }}$ groupsexperienced burning sensation decrease by $15.6 \%\left(\chi^{2}=1.6\right.$; $\mathrm{p}>0.05)$ and $34.4 \%\left(\chi^{2}=6.9 ; \mathrm{p}<0.05\right)$ respectively. Painful cold sensation insignificantly decreased by $6.3 \%\left(\chi^{2}=0.291 ; p>0.05\right)$ in group 1 and by $5.7 \%\left(\chi^{2}=0.3 ; p>0.05\right)$ in group 2 . The sensation of electric shocks was reduced by $28.13 \%$ $\left(\chi^{2}=6.5 ; p<0.05\right)$ in the patients of the $1^{\text {st }}$ group and by $28.13 \%\left(\chi^{2}=5.9 ; p<0.05\right)$ in those of group 2. Tingling worried the patients with diabetes less by $15.6 \%\left(\chi^{2}=1.6 ; p>0.05\right)$ of group 1 and by $22.9 \%\left(\chi^{2}=4.2 ; p<0.05\right)$ of group 2 . Pins and needles as well as numbness decreased by $21.88 \%\left(\chi^{2}=3.1 ; p<0.05\right)$ and $3.1 \%\left(\chi^{2}=3.1\right.$; $p>0.05)$ in the patients of the 1 st group, and by $25.7 \%\left(\chi^{2}=4.629 ; p<0.05\right)$ and $28.6 \%\left(\chi^{2}=5.7\right.$; $\mathrm{p}<0.05)$ in those of the 2 nd group. Itching began to bother less the respondents of the $1^{\text {st }}$ group by $3.1 \%\left(\chi^{2}=0.1 ; p>0.05\right)$ and by $14.3 \%\left(\chi^{2}=1.7\right.$; $p>0.05)$ those in the $2^{\text {nd }}$ group. The pain, which was localized in the area of reduced sensitivity to touching, decreased by $15.6 \%\left(\chi^{2}=1.9\right.$;

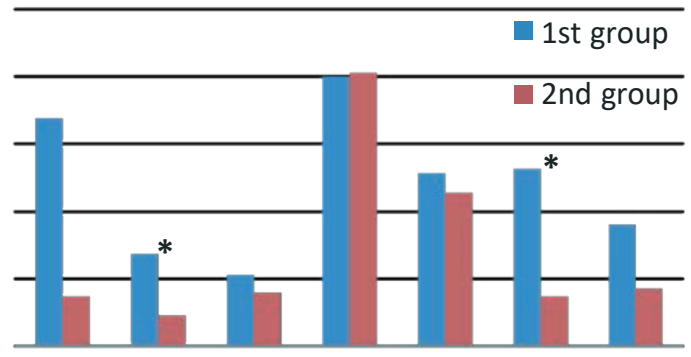

In 12 days after treatment

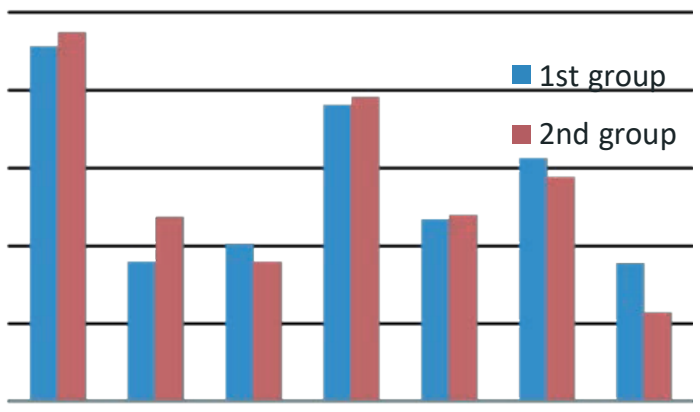

In 6 months after treatment

Fig. 1. Comparison of the intensity of complaints between the patient groups undergoing treatment. Notes: sensation of 1 - burning; 2 - painful cold; 3 - electric shocks; 4 - tingling; 5 - pins and needles; 6 - numbness; 7 - itching; $*-p<0.05$. 
$\mathrm{p}>0.05)$ and $14.3 \%\left(\chi^{2}=1.4 ; \mathrm{p}>0.05\right)$, to pricking by $25 \%\left(\chi^{2}=4.4 ; p<0.05\right)$ and $22,9 \%\left(\chi^{2}=4.6\right.$; $\mathrm{p}<0.05)$, and to irritation with a brush by $6,5 \%$ $\left(\chi^{2}=0.3 ; p>0.05\right)$ and $5.71 \%\left(\chi^{2}=0.7 ; p<0.05\right)$ in the examined groups 1 and 2 , respectively (Table 3).

The survey of the patients in 3 months after the treatment, proved that in the $1^{\text {st }}$ group such sensations as burning, painful cold, electric shocks, tingling, pinsand needles, numbness and itching were experienced by $17(53.1 \%), 10$ (31.3\%), 12 (37.5\%), 20 (62.5\%), 10 (31.3\%), 18 $(56.3 \%)$ and $9(28.1 \%)$ patients, whereas in the 2nd group - by $7(20 \%), 8(22.9 \%), 6(17.1 \%), 23$ $(65.7 \%), 14(40 \%), 11(31.4 \%)$ and $7(20 \%)$ patients respectively.

The analysis of survey of the patients with diabetes mellitus, conducted in 6 months after the treatment, proved that the patients with diabetes had sensations of burning, painful cold, electric shocks, tingling, pins and needles, numbness and itching in $22(68.5 \%), 12$ (37.5\%), $14(43.8 \%), 22$ (68.5\%), $15(46.9 \%), 21$ $(65.6 \%)$ and $9(28.1 \%)$ cases in group 1, and in $23(65.7 \%), 10(28.6 \%), 13(37.1 \%), 26(74.3 \%)$, $20(57.1 \%), 14(40 \%)$ and $12(34.3 \%)$ cases in group 2 respectively. The comparison of complaints intensity between the patient groups is presented in Fig. 1.

\section{Discussion}

The results of our study are consistent with the recent literature [1]. The standard therapy (a-lipoic acid, actovegin and complex of vitamins of the group B) decreases the intensity of pain and neuropathic disorders [11]. The adding of light therapy procedures allows not only the achievement of this effect, but also its long-term preservation $[10,12]$. The use of the questionnaire DN4 has long been practiced for the diagnosis of neuropathic pain $[13,14]$, but only its modification [9] allows evaluating the therapy effectiveness. The obtained results prove that significant improvement in the DN4 questionnaire's quantitative indicators occurred in 12 days after the beginning of treatment and persisted for three months after the treatment in both groups. At the same time, the intensity of the indicators of block 1 of the questionnaire in three months after the treatment was considerably less signifi in the patients who received additional light therapy. Six months later, quantitative and qualitative indicators of the presence and intensity of neuropathic pain resumed to the initial level.

\section{Conclusions}

Using a modified DN4 questionnaire in the patients with type 2 diabetes can improve the diagnosis of neuropathic pain.

Table 3. Follow-up of neuropathic pain intensity in the examined groups of patients under the influence of therapy $(M \pm \sigma)$

\begin{tabular}{|c|c|c|c|c|c|c|c|c|c|}
\hline \multirow{3}{*}{ 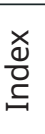 } & Before & \multicolumn{3}{|c|}{ After treatment in } & \multirow{2}{*}{ p1 } & \multirow{2}{*}{ p2 } & \multirow{2}{*}{ p3 } & \multirow{2}{*}{$\mathrm{p} 4$} & \multirow{2}{*}{ p5 } \\
\hline & treatment & 12 days & 3 months & 6 months & & & & & \\
\hline & \multicolumn{9}{|c|}{$1^{\text {st }}$ group } \\
\hline 1 & $4.7 \pm 3.7$ & $1.7 \pm 1.9$ & $1.7 \pm 1.9$ & $4.6 \pm 3.5$ & $<0.05$ & $>0.05$ & $<0.05$ & $<0.05$ & $>0.05$ \\
\hline 2 & $2.3 \pm 3.3$ & $0.7 \pm 1.3$ & $0.8 \pm 1.3$ & $2.4 \pm 3.4$ & $<0.05$ & $>0.05$ & $<0.05$ & $<0.05$ & $>0.05$ \\
\hline 3 & $2.3 \pm 3.4$ & $0.5 \pm 1.5$ & $0.6 \pm 0.8$ & $2.0 \pm 2.6$ & $<0.05$ & $>0.05$ & $<0.05$ & $<0.05$ & $>0.05$ \\
\hline 4 & $3.6 \pm 3.5$ & $2.0 \pm 2.6$ & $2.2 \pm 2.1$ & $3.8 \pm 3.2$ & $<0.05$ & $>0.05$ & $<0.05$ & $<0.05$ & $>0.05$ \\
\hline 5 & $2.2 \pm 3.7$ & $1.3 \pm 2.3$ & $1.4 \pm 2.2$ & $2.3 \pm 3.1$ & $<0.05$ & $>0.05$ & $<0.05$ & $<0.05$ & $>0.05$ \\
\hline 6 & $3.0 \pm 3.3$ & $1.3 \pm 2.2$ & $1.5 \pm 1.7$ & $3.1 \pm 2.9$ & $<0.05$ & $>0.05$ & $<0.05$ & $<0.05$ & $>0.05$ \\
\hline 7 & $1.750 \pm 2.828$ & $0.9 \pm 1.9$ & $1.7 \pm 2.9$ & $1.8 \pm 3.1$ & $<0.05$ & $>0.05$ & $<0.05$ & $<0.05$ & $>0.05$ \\
\hline \multicolumn{10}{|c|}{$2^{\text {nd }}$ group } \\
\hline 1 & $5.1 \pm 3.8$ & $0.2 \pm 0.4$ & $0.3 \pm 0.6$ & $4.7 \pm 3.9$ & $<0.05$ & $>0.05$ & $<0.05$ & $<0.05$ & $>0.05$ \\
\hline 2 & $2.1 \pm 3.5$ & $0.5 \pm 1.0$ & $0.5 \pm 1.1$ & $1.8 \pm 3.1$ & $<0.05$ & $>0.05$ & $<0.05$ & $<0.05$ & $>0.05$ \\
\hline 3 & $2.4 \pm 3.2$ & $0.4 \pm 1.0$ & $0.5 \pm 1.3$ & $1.8 \pm 2.6$ & $<0.05$ & $>0.05$ & $<0.05$ & $<0.05$ & $>0.05$ \\
\hline 4 & $4.3 \pm 3.1$ & $2.0 \pm 2.0$ & $2.0 \pm 2.6$ & $3.9 \pm 3.1$ & $<0.05$ & $>0.05$ & $<0.05$ & $<0.05$ & $>0.05$ \\
\hline 5 & $2.5 \pm 2.5$ & $1.1 \pm 1.8$ & $1.3 \pm 1.8$ & $2.4 \pm 2.4$ & $<0.05$ & $>0.05$ & $<0.05$ & $<0.05$ & $>0.05$ \\
\hline 6 & $3.6 \pm 3.3$ & $0.4 \pm 0.5$ & $0.5 \pm 0.9$ & $2.9 \pm 3.7$ & $<0.05$ & $>0.05$ & $<0.05$ & $<0.05$ & $>0.05$ \\
\hline 7 & $1.7 \pm 2.8$ & $0.4 \pm 1.0$ & $0.5 \pm 1.3$ & $1.1 \pm 2.3$ & $<0.05$ & $>0.05$ & $<0.05$ & $<0.05$ & $>0.05$ \\
\hline
\end{tabular}

Notes: sensation of $\mathbf{1}$ - burning; 2 - painful cold; $\mathbf{3}$ - electric shocks; $\mathbf{4}$ - tingling; $\mathbf{5}$ - pinsand needles; $\mathbf{6}$ - numbness; 7 - itching; p1 - significant differences of indexes before and in 12 days after treatment; p2 - significant differences of indexes in 12 days and in 3 months after treatment; p3 - significant differences of indexes before and in 3 months after treatment; p4 - significant differences of indexes in 12 days and in 6 months after treatment; p5 - significant differences of indexes before and in 6 months after treatment. 
The presence of phototherapeutic procedures by the Bioptron together with the standard complex therapy of diabetic polyneuropathy has a pronounced clinical effect and contributes to a 3-month-long reduction of quantitative and qualitative indicators of neuropathic pain.
The temporary clinical effect of the use of polarizing light in the treatment of diabetic polyneuropathy proves the feasibility of studying new therapies that would influence the pathogenesis of neuropathic pain.

\section{ОПИТУВАЛЬНИК DN4 У ПРАКТИЦІ СІМЕЙНОГО ЛІКАРЯ ДЛЯ ОЦІНКИ НЕЙРОПАТИЧНОГО БОЛЮ У ХВОРИХ 3 ЦУКРОВИМ ДІАБЕТОМ 2-ГО ТИПУ ПРИ ЛІКУВАННЯ СВІТЛОТЕРАПІЕЮ}

\section{ТЕРНОПІЛЬСЬКИЙ ДЕРЖАВНИЙ МЕДИЧНИЙ УНІВЕРСИТЕТ IМЕНІ І. Я. ГОРБАЧЕВСЬКОГО, ТЕРНОПІЛЬ, УКРАЇНА}

Вступ. Периферична діабетична полінейропатія є одним з найбільш частих неврологічних ускладнень цукрового діабету. Незважаючи на широкий спектр існуючих лікарських засобів, ї̈ лікування є недостатньо ефективним, що зумовлює пошук нових статегій та засобів.

Мета дослідження - підвищити ефективність лікування нейропатичного болю у хворих на цукровий діабет шляхом включення процедур із використанням поляризаційного поліхромного некогерентного світла (біоптронна світлотерапія).

Методи. Обстежено 67 хворих на діабет 2 mипу, який ускладнений діабетичною поліневропатією. Пацієнтів було розділено на дві групи: 1 група - 32 пацієнтів, які отримали стандартне лікування; 2 група 35 хворих, які додатково пройшли 12 процедур світлотерапії за допомогою світлотерапевтичного пристрою Біоптрон. Оцінку інтенсивності невропатичного болю проводили за допомогою модифікованої анкети DN4.

Результати. Через 12 днів лікування позитивний клінічний ефект лікування спостерігався в обох групах. Однак, через 3 місяці інтенсивність скарг була значно меншою $(p<0,05)$ в 2-ій групі пацієнтів, які отримували додатково лікування поляризаційним світлом. Через 6 місяців ефект терапї був однаковим у пацієнтів обох груп.

Висновки. Використання опитувальника DN4 з модифікованою шкалою для оцінки параметрів нейропатичного болю може оптимізувати його діагностику та оцінку. Світлотерапевтичні процедури у поєднанні зі стандартною комплексною терапією діабетичної поліневропатії підвищують клінічну ефективність лікування невропатичного болю і допомагають зберегти терапевтичний ефект протягом 3 місяців.

КЛЮЧОВІ СЛОВА: діабетична поліневропатія; невропатичний біль; опитувальник DN4; поляризоване поліхроматичне некогерентне світло (Біоптрон).

\section{References}

1. Pankiv IV. Efficiency of alpha lipoic acid therapy at diabetic foot syndrome. Pain. 2014;3(59):108-114.

2. Bansal D, Gudala K, Muthyala H, et al. Prevalence and risk factors of development of peripheral diabetic neuropathy in type 2 diabetes mellitus in a tertiary care setting. Diabetes Investig. 2014; 5:714721.

3. Mardzvik VM. Efficacy of Neogabyn in treatment of postherpatic neuralgia. Ukrainian Journal of Psychoneurology. 2015;1(82):137-140 [In Ukrainian].

4. Borenstayn D. Epidemiology, etiology, diagnostic evaluation and treatment of lumbar pain. International Medical Journal. 2000;1:36-43 [In Russian].

5. Dedov II, Shestakova MV, Mayorov AY. Standards of specialized diabetes care. 8th Edition. Moscow.: PRINT Publishing Company; 201760. Available at http://webmed.irkutsk.ru/doc/pdf/ algosd.pdf [In Russian].

6. Yang W, Dall TM, Halder P, Gallo P, Kowal SL, Hogan PF. Economic costs of diabetes in the U.S. in 2012. Diabetes Care. 2013;36(4):1033-1046.

7. Alleman CJ, Westerhout KY, Hensen M, et al. Humanistic and economic burden of painful diabetic peripheral neuropathy in Europe: A review of the literature. Diabetes Res. Clin. Pract. 2015;2:215-225.

8. Gulyar SA. Anthology of lightt herapy. Medical BIOPTRON technology (theory, practice, prospects). The book of scientific works. Kiev. IFB of NAS of Ukraine. 2009;1024 [In Russian].
9. Martynyuk LP, Shved, MI, Makarchuk NR, Chernetskyi VI. East European Scientific Journal. 2018;1(29):39-41.

10. LimanskiyYu.P. The phenomenon of analgesia under the action of PILER-light apparatus BIOPTRON on point acupuncture. Anthology of light therapy. The book of scientific works. Kiev. IFB of NAS of Ukraine. 2009:184-189 [In Russian].

11. Unified clinical protocols of primary, emergency and secondary (specialized) medicalhelp: diabetes mellitus type 2. Available at http://old.moz. gov.ua/ua/portal/dn_20090805_574.html [In Ukrainian].

12. Gulyar SA, Limansky YuP, Tamarova ZA. Pain and BIO PTRON : treatment of pain syndromes by polarized light. Zepter. 2000 [In Russian].

13. Povoroznyuk VV. Neuropatic component of pain in skeletal-muscle in diseases. Pain. Joints. Spine Part I. 2014;4(16):5-13 [In Ukrainian].

14. Mathieson S, Maher CG, Terwee CB, Follyde Campos T, Lin CW.J Clin Epidemiol. Neuropathic pain screening questionnaires have limited measurement properties. A systematic review. 2015;68(8):957-66.

15. Bregovskiy VB. Painful diabetic polyneuropathy of the lower extremities: current knowledge and treatment options (review). Pain. 2008;1(18);2934 [In Russian]. gov.ua/ua/portal/dn_20090805_574. html [In Ukrainian]. 